ROCZNIKI HUMANISTYCZNE

Tom LXIX, zeszyt 11 - 2021

ZESZYT SPECJALNY/SPECIAL ISSUE

DOI: https://doi.org/10.18290/rh216911-4s

AIDAN DOYLE

\title{
IRISH SPEAKERS AND THEIR EXPERIENCE OF EMIGRATION TO NORTH AMERICA*
}

\begin{abstract}
A b s t r a c t. In historical work on emigration from Ireland to the New World, it has become widely accepted that Irish speakers were more passive and fatalistic than English speakers, and that they felt that emigration was a form of exile. This article challenges this assumption. In the first part, it is shown that the linguistic argument for this claim lacks both theoretical and empirical foundations. The evidence for Irish, it is shown, does not indicate any passivity on the part of its speakers. In the second part of the article, accounts of life in America by Irish speakers are drawn upon. On the whole, these suggest that Irish speakers, like English speakers, had a wide range of experiences in their new environment. However, they fail to show that language played a significant role in any feelings of alienation among emigrants.
\end{abstract}

Keywords: emigration; Whorf; Miller; modality; exile.

\section{INTRODUCTION}

Over the last forty years, the fate of the Irish language in North America has attracted the interest of scholars on both sides of the Atlantic. One of the first publications devoted to this topic was the collection of essays Go Meiriceá siar (Ó hAnnracháin). This was followed by various works from the pen of Kenneth Nilsen ("Thinking of Monday," "The Language"). Mahon's Thomas Griffin (1829-96) is a study of the life of an Irish-speaking emigrant from Corca Dhuibhne, County Kerry. In more recent times, the subject of Irish in the New World has been dealt with in some of the essays in Litriocht na

Aidan Doyle, PhD, Dr. Litt., University College Cork, Department of Modern Irish; e-mail: a.doyle@ucc.ie.

${ }^{*}$ This article was substantially revised in response to the remarks of three anonymous reviewers, whom I would like to thank for their questions and suggestions. 
Gaeilge (Nic Congáil et al.), and in North American Gaels (Sumner and Doyle). Danny Doyle's Mile Míle i gCéin is a monograph devoted to the Irish language in Canada, which also forms the subject-matter of Nilsen's "An Ghaeilge." Finally, $\mathrm{Ar}$ an gCoigcrioch (Ní Dhonnchadha and Nic Eoin) contains many accounts by emigrants of their time in North America.

Emigrants and Exiles by Kerby Miller is perhaps the most influential work on Irish emigration to North America to emerge in the last forty years. The author was the first historian to include the Irish language in his account, which is greatly to his credit. Irish language sources are quoted in every chapter. Miller argues that Irish speakers experienced emigration differently from English speakers; specifically, he maintains that emigration was for them much more painful and alienating than for Anglophones. This in turn, led to their being less successful in America than other emigrants from Ireland. According to Miller, this claim can be substantiated by analysing the linguistic structure of Irish and English.

Miller's assessment of the experience of Irish emigrants and its causes has been accepted without question by many other authors dealing with this subject such as Kenny, Meagher, and Ní Bhroiméil. ${ }^{1}$ The following quotation from Kenny's The American Irish is representative: "Irish speakers from more remote regions of Ireland, by contrast, still tended to see emigration in terms of tragedy and alienation, a conception they seem to have retained until the catastrophe of the 1840s and in many cases beyond" (Kenny 51). The author explicitly mentions Miller as the source for this statement. Likewise, we read in Ní Bhroiméil (9): "Kerby Miller in his seminal work, Emigrants and exiles,... argues that the structure of the Irish language contributed to the passivity, fatalism and dependence of Irish emigrants who were thus predisposed to look upon their emigration as exile"; the author does not challenge this statement.

The one exception to this general acceptance is McQuillan (Native and Natural). ${ }^{2}$ This author argues that Miller's thesis is flawed in terms of the linguistic theories of Benjamin Whorf, the very scholar that Miller invokes to support his view of Irish speakers in the US (McQuillan, Native and Natural 164-167). I am in agreement with McQuillan. Indeed, if his work were more widely known, part of this essay would be redundant. As this is not the case, and as the relevant passage in McQuillan is to be found in a book which has

\footnotetext{
${ }^{1}$ McCaffrey disagrees with Miller regarding the success of the post-Famine emigrants, but he makes no mention of the language issue in his work.

${ }^{2}$ Thanks to the reviewer who drew my attention to this work.
} 
nothing to do with emigration, I will begin by presenting briefly Miller's theory and McQuillan's critique of it, and then add some more data and criticism of my own.

\section{THE STRUCTURE OF IRISH}

\subsection{Language and thought}

Chapter 3 of Emigrants and Exiles has the title "Continuity: The culture of exile." In it, the author examines the view of emigration as exile in Gaelic literature. In the final section, Miller puts forward a theory about the influence that the structure of the Irish language exerted on its speakers: "Finally, the semantic structure of the Irish language itself reflected and reinforced an Irish worldview which emphasized dependence and passivity" (119). According to Miller, "the English language is weighted toward action, control, independence" (120). On the other hand, "the Irish language categorizes experience as either active or stative, and by making the distinction between the categories overt in the structure of sentences, forces an awareness of that distinction upon the Irish-speaker in a much stronger way than does a nominative language such as English, where the distinction remains covert" (120). He states further that "in practical usage Irish-speakers frequently chose a stative over an active way of expressing behavior, thereby demonstrating the interplay among historical tradition, worldview, and the categorical choices which a language offers" (120-21).

Miller subscribes to the view that "[w]ords, like all linguistic phenomena, are social facts and do not exist apart from the particular culture which employs them as a means of communication" (105). He specifically refers to the linguistic theory of Benjamin Whorf to support the above claim: "Scholars such as B. L. Whorf have argued that a careful examination of words, both etymologically and in their relationship with others in the same semantic system, can reveal much about the structure and thought of a given society" (105). In the same vein, he writes: "Languages and the cultures related to them ... variously influence the received world, and hence the outlook, of their speakers" (119).

McQuillan objects to Miller's approach on the grounds that it distorts Whorf's message: 
Whorf crucially eschews any direct cause and effect between grammatical structure and cultural practice: his main concern was with the possible relation between this kind of pervasive linguistic structure and habitual thought and behaviour, whereby the habitual mode of the individual is shaped by analogous "fashions of speaking." (McQuillan, Native and Natural 166) [all emphases original]

He then goes on to examine Miller's demonstration of the connection between language and thought with respect to emigration. Linguistic structure, for Miller, has a direct bearing on how Irish and English speakers saw emigration:

[A]n English-speaker might either say "he went to America" or "he had to go to America," depending upon whether the speaker wished to express independent volition or passive necessity in the particular instance. The Irish-speaker can [emphasis original] employ a phrase, d'imthigh sé go Meirice, which conveys the sense of purposeful action. However, in terms of the central thesis of this work, it is very significant that by far the most common way for an Irish-speaker to convey his emigration has been dob éigean dom imeacht go Meirice "I had to go to America"; ... Thus, Irish-speakers chose a patient [sic] over an active way of expressing their emigration.... In short, dob éigean dom imeacht go Meirice meant that emigration was fate rather than choice, necessity rather than opportunity. (Miller 121)

McQuillan discusses this passage, remarking: "If [emphasis original] Irishspeakers choose mode X over mode $Y$... they are simply making a choice based on their cognitive appropriation of a given situation, and therefore there can be no question of a passively or fatalistically induced world view" (McQuillan, Native and Natural 167).

It is not possible to adequately present McQuillan's discussion without straying from the main focus of this article. I mention it mainly to show that in terms of the linguistic theory of Whorf, Miller's claim has been challenged. I wish to concentrate now on the particulars of his suggestion above concerning the preferences of Irish speakers for describing emigration.

\subsection{Testing the hypothesis}

In his claim about how Irish speakers describe emigration, Miller seems to be making a distinction between a verb with an overt subject and a construction expressing necessity:

(1) a. D’imigh mé go Meirice. went I to America

b. Dob éigean dom imeacht go Meirice. particle necessity for.me go.VN to America 
He then states that "by far the most common way for an Irish-speaker to convey his emigration has been dob éigean dom imeacht go Meirice 'I had to go to America'" (121). We are not told on what this statement is based. ${ }^{3}$ In linguistic work, it is customary to provide some kind of statistical evidence drawing on fieldwork or language corpora, particularly when dealing with a language not one's own. There is a problem in this particular instance, in that most of the Irish-language interviews and written accounts which deal with emigration are from the twentieth century. Thus, there is no way of establishing with total certainty the truth or falsehood of Miller's assertion. However, given that some of the people who have left accounts of emigration were born before 1900, we can attempt some assessment of its veracity. After all, the living conditions in Gaeltacht areas in the period 1870-1920 were not significantly different from those in the $1850 \mathrm{~s}$. A search of material relating to emigration should enable us to form a better idea of how Irish speakers tended to view it.

To begin with, here are the words of one emigrant from Conamara, recalling how she left home in the 1920s:

(2) O, go maith, cuimhním ar a' lá ar imigh mé go maith. Nuair a dúirt mé 'beannacht leat' le m'athair (bhfuil tú ag iarradh é sin innseacht, yeah) agus cuimhnim a' rud a dúirt sé 'A, muise, a leanbh, ni fheicfe mé go brách arist thú.' (Nilsen, "Thinking of Monday" 8)

Oh, right, I remember well the day I left. When I said "God bless" to my father (do you want me to tell you that, yeah) and I remember what he said, "Ah, musha, my child, I'll never see you again."

The setting is clearly emotional. The reason for leaving was economic necessity. In Miller's terms, the emigration was involuntary, and as such we would expect the speaker to employ the subjectless dob éigean dom 'it was necessary for me'. Instead, we find the verb imigh 'go' (underlined in the citation) with a subject $m e$ ' 'I'. In other words, this passage clearly contradicts the claim made by Miller.

This is not an isolated example. The texts in Ní Dhonnchadha and Nic Eoin provide us with a good selection of descriptions of emigration from every

\footnotetext{
${ }^{3}$ McQuillan (Native and Natural 167) makes the same comment.

${ }^{4}$ A reviewer asks whether we would expect this exact phrase in this dialect. There are a number of phrases available in each dialect of Irish, including the active modal caith, which are used to express necessity. If Miller is correct, then we would expect one of these phrases. The point I am trying to make is that the speaker did not use a term denoting obligation to describe their leaving of Ireland.
} 
Irish-speaking district. I have gone through ten of these in search of phrases relating specifically to the act of going to another country. The results are laid out under (3)-(4) below. Relevant uses of a verb of motion (imigh or téigh) with subject, and a construction of necessity are underlined. An abbreviation and an approximate date is provided for each text. The abbreviation AC refers to the anthology Ní Dhonnchadha and Nic Eoin.

(3) a. Bhí Niall Phádruig ag imtheacht go Meiriceá... Acht, ar ndóigh, an chuid a b'fhearr de na fir a d'imthigh. An oidhche sul ar imthigh sé bhi an baile cruinn i dtigh 'athara. AC: 61 (RF, c. 19005)

'Niall Phádruig was going to America.... But of course, it was the best of the men that went. The night before he went the townland gathered in his father's house.'

b. Sé bliana déag a bhí mé nuair a chuaigh mé go hAlbain. AC: 324 (NBMO, 1905)

'I was 16 years old when I went to Scotland.'

c. Chaointí an té a bheadh ag imtheacht trí huaire. AC: 65 (RMS, c. 1880)

'The person who would be going used to be lamented three times.'

d. Raghad go hAimeiriceá. AC: 67 (MT, c. 1870)

'I'll go to America.'

e. Bé nós a bhí ann san am san, gach duine beag agus mór de mhuintir an pharóiste ar fad do dhul ag tionlacan an té a bheadh ag imeacht go dtí Meiriceá. AC: 71 (P, c. 1891)

'The custom at the time was, everybody, young and old, in the parish would accompany the person who was going to America.'

f. Sé mhí ina dhaidh sin thóg mo mhac Pádraig a sheolta agus d'imigh leis go dtí an tOileán Úr. AC: 73 (P, c.1920)

'Six months later my son Patrick upped and went off to the New World.'

g. Niorbh é an té a bhí ag imeacht ba mheasa as. AC: 77 (BB, c. 1920)

'The person who was leaving was not the worst affected.'

h. Is cuimhin liom go maith an oíche sara n'imigh sé. AC: 78 (SD, 1948)

'I remember well the night before he left.'

\footnotetext{
${ }^{5}$ No date is provided for the publication of this book, but the author was born in 1889 , and the book is about Rann na Feirste in his youth.
} 
i. Bhí triúr eile de bhuachaillí óga an pharóiste ag dul ar imirce chomh maith. Ba i an bhliain chéanna a d'imigh comharsa béal dorais dúinn, Dave Russell, thar lear. AC: 83 (TNTO, 1959)

'Three other young lads from the parish were emigrating as well. That was the same year that our next-door neighbour Dave Russell went abroad.'

j. Ba é Patch ba thúisce a d'imigh. AC: 98 (CS, c.1950)

'Patch was the first to go.'

(4) a. Bhí sé fiordhílis dá thír agus dá theangain dúchais is ní raibh fonn air í a fhágaint go deo. Ach ní mar sin do tharlaigh. B'éigean dó imeacht agus bóthar na coda eile do thabhairt air go bristechroíoch agus go brónach. AC: 73 (P, c. 1920)

'He was really true to his country and his native language and he had no wish to leave it ever. But that's not how it was. He was forced to go and to follow the others broken hearted and sad.'

b. Do na fir chaocha agus bhacacha agus bhodhra is fiú a bheith dilis d'Eirinn. Ní call d'aon duine dá dteaghlaighsean dul ar imirice! AC: 159 (C, 1953)

'For the blind and the lame and deaf, it's worth being loyal to Ireland. None of their children are forced to emigrate!'

In (3), we have thirteen verbs of motion with a subject. In (4), we find two cases of a construction with $d o$ expressing necessity. In the light of these findings, it is difficult to see how Miller's assertion about the frequency of usage of the respective linguistic patterns can be maintained.

\subsection{Semantics and syntax}

There is another, general linguistic issue which bears on the subjectless construction, and its supposed influence on modes of thought. Let us look at the sentence again:

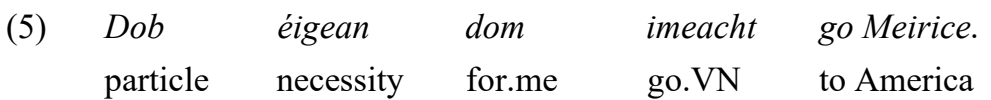

According to Miller, "this sentence belongs to a type known in Irish grammar as 'impersonal', and the function of such sentences is precisely to downgrade active participation and present inexorable fact" (121). A few comments are in order here. First of all, this is not an impersonal. Irish does have impersonals, where the subject is not expressed: 
(6)
Chuathas
go Meiriceá.
go.Past.Impersonal
to America
'People (unspecified)
went to America.'

But these are distinct from the example in (5). dob éigean do is a construction expressing the modality of necessity or obligation. In (5), we have two clauses: the main clause dob éigean dom + complement and a non-finite subordinate clause dul go Meirice with the verbal noun, which is functionally equivalent to an infinitive in other languages. There is a personal participant in (5), expressed in the inflected preposition dom 'to me'. Second, all modals of necessity "downgrade active participation and present inexorable fact," if by inexorable fact we mean lack of choice. That is the whole point of these modals. The English sentence "I had to go to America" does not ascribe any more agency to the subject than the Irish construction in (5). Furthermore, Irish has a verbal modal caith which is used with a subject:

$\begin{array}{llll}\text { (7) Chaith } & \text { mé } & \text { dul } & \text { go Meirice. } \\ \text { must.Past } & \text { I } & \text { go.VN } & \text { to America }\end{array}$

This is an exact equivalent of (5): both express lack of agency and volition on the part of the person involved. By omitting to mention this common verb, Miller creates a distorted picture of the structure of Irish-it looks as if the only way of conveying obligation is by means of the construction in (5). ${ }^{6}$ One could equally well take the sentence It was necessary for me to go to America, and claim that it represented the lack of choice and fatalism of English speakers.

There is nothing terribly remarkable about the subjectless construction of Irish: ${ }^{7}$ many languages offer similar constructions, with the person marked either by a preposition or a case such as the dative, or without any mention of the person at all. Even in a limited Indo-European context, English is very often the exception rather than the rule when it comes to how participants are syntactically realised. Take the verb like. English is unusual in that the person experiencing the emotion is in the subject position, rather than occurring in the dative or as the object of a preposition:

\footnotetext{
${ }^{6}$ This predicate is confined to the past and conditional, lacking forms for present and future.

${ }^{7}$ If English is one's yardstick for what is normal, then of course most languages are exotic.
} 
(8) a. I like this picture.

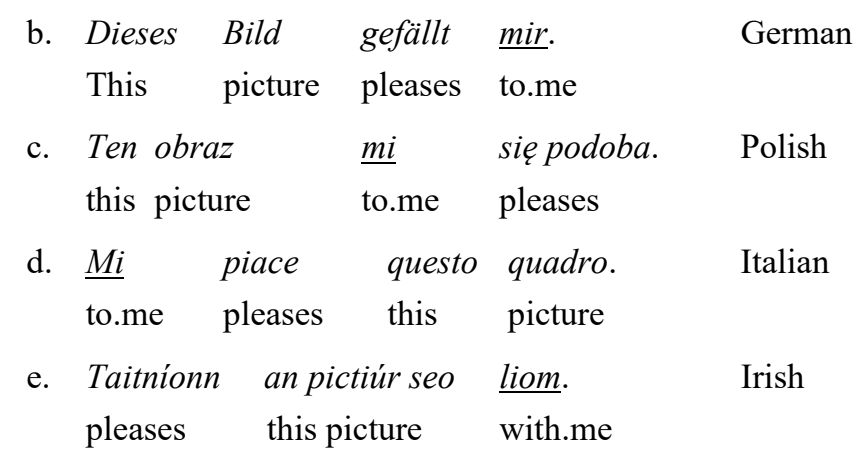

In (b)-(e), the source of pleasure is in the subject position, the experiencer in the dative or governed by a preposition. In (8a) the source of pleasure is in the object position, the experiencer is the subject. I am not sure that this enables us to draw any conclusions about the habitual thoughts of Anglophones, or what those thoughts would be.

Likewise, as far as I know, every natural language offers the possibility of expressing different kinds of modality. ${ }^{8}$ One can simply assert that something happened, with a declarative sentence. Or one can express a certain attitude to the same event, by means of a morphological mood like the subjunctive or an auxiliary like must or have in English. Verbs are one way of expressing modality, but not the only one. Consider these data from Polish:

(9)

$\begin{array}{ll}\text { Musiatam } & \text { wyjechać } \\ \text { I.must.PastFem. } & \text { emigrate }\end{array}$

or: wyjechać necessary was do Stanów Zjednoczonych

to USA (modal auxiliary)

In (9), we find an auxiliary verb with overt subject, in (10) an impersonal predicate trzeba, with no expression of the person involved. The choice of one or the other will depend on a whole range of factors, but the obligation is the same in both. (10) is not more final or irrevocable than (9).

This is not to deny that an experience like emigration may be felt and viewed differently by two individuals, and that this will be reflected in

\footnotetext{
${ }^{8}$ For modality in Irish, see McQuillan (Modality and Grammar).
} 
language. If a speaker feels that they had no choice but to emigrate, then there is every chance that they will use a construction which expresses necessity. For an Irish speaker, that might be do b'éigean dom (as in (5) above). But as we have seen in section 2.1 , as often as not there will simply be a bare assertion:

$$
\begin{array}{lll}
\text { (11) D'imigh mé } & \text { go Meirice. } \\
\text { went.Past } & \text { I } & \text { to America }
\end{array}
$$

Miller's presentation suggests that the two constructions are in free variation: "Thus, Irish-speakers chose a patient over an active way of expressing their emigration" (Miller 121). But they are not equivalent, any more than the following sentences are:

\section{(12) a. I emigrated. \\ b. I had to emigrate / It was necessary for me to emigrate.}

Irish, like other languages, has various means at its disposal to express different kinds of modality, depending on the context. The employment of one or the other of these in turn alters the meaning of the sentence. I fail to see how this indicates a particular world view for the speakers of any language.

Miller concludes his presentation on the linguistic structure of Irish thus: "The message of the sentence is entirely consistent with the equally common use of the word deorai (exile) to designate 'emigrant', as one subject to imposed pressures. In short, dob éigean dom imeacht go Meirice meant that emigration was fate more than choice, necessity rather than opportunity" (121). We now turn to a consideration of the word deorai, with a view to ascertaining if there is any basis for this claim about its usage.

\section{THE SEMANTICS OF DEORAÍ AND DEORAÍOCHT}

The main argument in chapter 3 of Miller is that for Irish speakers, emigration was exile. The author sees this view as inherent in the very word for emigrant in Irish:

It may be very significant that the Irish language had no equivalent for the English word "emigrant," with its voluntary and neutral connotations. Rather, the Irish word primarily used to describe one who left Ireland has been deorai, the literal meaning of which is "exile." ... Thus, the Irish language, when combined with the poets' interpretation of 
postconquest Irish history, provided both linguistic patterns and heroic models to predispose the Catholic Irish to regard all those who left Ireland as unwilling and tragic political exiles. (Miller 105)

In what follows, I will examine the semantics and usage of deorai and the abstract noun deoraiocht derived from it.

\subsection{Deoraí and deoraíocht}

In medieval Irish (c. 700-c. 1500), deorad meant 'outlaw, (political) exile, pilgrim' (DIL ${ }^{9}$ ). Exile is to be understood here in a local sense, with reference to somebody who had to leave their tribe or fine, and did not necessarily imply a journey overseas. In some of the citations it means 'foreign mercenary'. The word is commonly used to refer to pilgrims. The semantics are thus much broader than modern English exile. Loingsech means 'a banished person, searover, pirate'. Its semantics thus seem to be closer to modern English exile. ${ }^{10}$

In Modern Irish (c. 1500-), the meaning of deorai ${ }^{11}$ seems to have gradually narrowed to that of 'stranger, wanderer, wretch' $(\mathrm{CnG}){ }^{12}$ In the seventeenth century, we still find the old meanings. The writings of Geoffrey Keating (1580-c.1644) contain several examples of the word. In his history of early Ireland, deorai is used of foreign mercenaries:

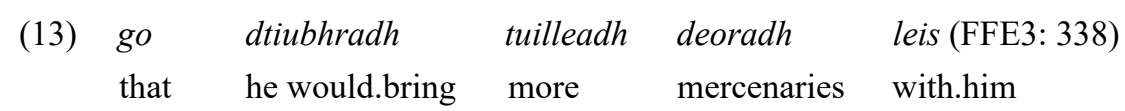

In a religious text by the same author, it would seem to mean 'exile':

(14) An seachtmhadh halt as a dtuigthear gurab cosmhail Ádhamh ré deóraidh dobhiadh ar dibirt i gcoigcrich. (TBB: 114)

'The seventh chapter from which is deduced that Adam is like an exile who would have been banished to a foreign country.'

Here, the relative clause following deóraidh expressly mentions 'banishment' (ar dibirt i gcoigrich), and 'exile' would appear to be the most adequate gloss.

\footnotetext{
${ }^{9}$ For abbreviations see Data Sources at end.

${ }^{10}$ It is impossible to be absolutely certain about the connotations of a word used in a text more than 500 years ago. The glosses in DIL are approximations, but they are all we can go on.

${ }^{11}$ For Modern Irish, I use the standardised 20th-century spelling, although this rarely matches the spelling in the texts of $\mathrm{CnG}$.

${ }^{12}$ Corpas na Gaeilge $(\mathrm{CnG})$ is simply a database, without any meaning assigned to the items. My gloss 'stranger, wretch' is based on the examples included in $\mathrm{CnG}$.
} 
On the other hand, in a different passage in the same religious text, deorai seems to mean 'stranger, guest':

(15) a. Ionnus, mar aitheantar an deóraidh ar a bhéasgna cia an chríoch nó an cionnaidh is dúthaigh dhó. (TBB: 58)

'So that, as it is recognised by the manners of a stranger what his native country or tribe is.'

b. Do bhádhas im dheóraidh agus nior ghlac sibh ar aoigheacht me. (TBB: 225)

'I was a stranger and you did not take me in.'

(15b) is a translation of a line from Matthew 25, where deóraidh corresponds to hospes 'stranger' in the Vulgate original.

After 1700, the meaning 'stranger, wanderer, guest' is common:

(16) a. Seo mar dubhairt Aodhagán Ó Rathaille le deoruidhe tháinig ag iarraidh iostas oidhche air. (ER: 284)

'This is what Aodhagán Ó Rathaille said to a stranger who came looking for a night's lodging.'

b. Nuair do-chonnaic Marta an duadh agus an trioblóid dobhí uirri féin ag ullmhughadh beathadh dá deóraidhe. (SMN: 28)

'When Martha saw the effort and trouble that she was taking to prepare food for the guest.'

c. deóraidhthe nó strainnséirí (SMN: 178)

'deóraithe or strangers'

In some texts the meaning seems to be vaguer, something like 'wretch':

(17) a. Is iomdha deóraidhe diadha déarach, Flaith is triath fá chiadh it dhéidh-se

'Many pious, tearful wretches

Princes and chiefs dejected after you[r death]'

b. an bochtán agus an deóraidhe (SPS 2: 162)

'the poor person and the wretch'

It can also denote 'foreigner' in a negative sense, referring to the Protestant minority who ruled Ireland in the eighteenth century:

(18) na deóraidhthe craosacha claonmhara coimhtheach (TG: 81)

'the greedy prejudiced foreign aliens' 
Around 1850 the Ulster scribe Aodh Mac Domhnaill made a translation of Thomas Campbell's "Exile of Erin" (Beckett 169). Here, if anywhere, one might expect to find deorai used as 'exile'. But Mac Domhnaill translated exile as 'díbearthach', and stranger as 'deoraí'. After an exhaustive trawl of all the occurrences of deorai in CnG for the period 1700-1850, I have been unable to find a single example that would substantiate Miller's claim that "the Irish word primarily used to describe one who has left Ireland is deorai" (105).

The spoken language went largely unrecorded before the twentieth century. One might wonder whether the meaning 'exile' survived there from the Middle Ages, despite being lost in the literary language. I have consulted a number of oral Gaeltacht sources from the twentieth century (Breatnach; $\mathrm{CnG}$; de Bhaldraithe, Gaeilge Chois Fhairrge, English-Irish Dictionary; Lúcas; Mac Clúin; Ó Cuív; Ó Máille; Wagner). In these, deorai survives mainly in the phrase Ní raibh (duine ná) deorai ann 'There wasn't a sinner there'. It can also mean 'poor wretch'. There is no record of it in these sources of it being used as the equivalent of exile.

What probably ${ }^{13}$ misled Miller was that the word underwent semantic extension at the end of the nineteenth century in order to provide an equivalent for the English word 'exile, emigrant'. The earliest example, as far as I know, ${ }^{14}$ of this new use is from 1888, in the title of a poem in the New York newspaper The Irish American, "Cumha an deoraidh" (The exile's sorrow) (IA 10/03/1888: 3). Nine years later, we come across it being used in a speech about emigration:

(19) na deoraidhe [sic] dibeartha do thabhairt ar ais

(IG 8: 46) 'to bring back the banished exiles'

The new meaning must have caught on quite quickly, ${ }^{15}$ for we find it in the Gaelic League weekly An Claidheamh Soluis in 1899, where it appears in the title of a poem, "Caoineadh an déoraidh ó Éirinn" (Ua Conmhacáin 1899), this in turn being a translation of "The Irish Emigrant's Lament." It undoubtedly became part of the vocabulary of learners' Irish in the twentieth century, appearing in the dictionaries of McKenna and de Bhaldraithe (English-Irish Dictionary).

\footnotetext{
${ }^{13}$ One reviewer takes great exception to my use of the adverb probably. I have made every attempt to correct this, but I feel that its presence is justified in this instance.

${ }^{14}$ Thanks to Matthew Knight for providing me with this reference.

${ }^{15}$ As a reviewer points out, the publication of the novel Deoraidheocht (Ó Conaire) in 1910 helped to get the new meaning of deorai accepted.
} 
Not surprisingly, after 1900 deorai occurs quite frequently in the writings of Irish people in North America, many of whom were native speakers. Consider the following example from a poem written in the USA around 1913:

(20) An 'deorai' atá [ag] lorg na déirce (BM I: 6)

'The exile who is begging for alms'

But there is no evidence of it being used by illiterate ${ }^{16}$ nineteenth-century emigrants to describe emigration. Once again, Miller's claim proves to be unfounded.

The abstract noun deoraiocht occurs in the phrase ar deoraiocht 'in exile, wandering abroad'. This meaning was retained in both a literal and metaphorical sense after 1600, as the following excerpt from a text of Keating's illustrates:

(21) Measaim fós gomadh éigcrionna don tí dobhiadh ar deóraidheacht agus ar dibirt i gcoigrich óna thír... Mar an gcéadna adeirim gurab éigcrionna don fhíréan atá ar díbirt agus ar deóraidheacht i ndocamhal an tsaoghail se (TBB: 87)

I think moreover that it would be unwise for the person who would be wandering in exile from his land.... Likewise I assert that it is foolish for the righteous one who is wandering in exile in the distress of this world.

The second part of the excerpt shows ar deoraiocht being used as a metaphor for the wandering of the soul of the Christian in this world. Note also that $a r$ deoraiocht is used in conjunction with ar dibirt 'banished, exiled'. One could translate it either as a near synonym 'in exile', or as 'wandering'. This meaning of 'exile, being abroad' persists after 1700:

(22) Tá gliahdaire catha ar deóraidheacht sa Róimh mhín (CC: 26)

'There is a warrior [lit. gladiator] exiled in fair Rome.'

In fact, this meaning is widespread in the political poetry of the eighteenth century to refer to Irish Jacobites living on the Continent of Europe. It is also found in the learned writings of the nineteenth century:

(23) Ni mo bheidh siad-san air deoraigheacht a reugan choimhtheach. (LSB: 349)

'Nor will they be exiled in a foreign country.'

\footnotetext{
${ }^{16}$ Illiterate, that is, in Irish. Only a tiny percentage of Irish speakers learnt to read and write Irish before 1922, mainly during the revival period (1890-1920).
} 
It looks, then, as if the semantics of deoraiocht offer some support for Miller's claim about how the Irish viewed travel abroad.

However, the context in which the phrase ar deoraiocht occurs is very clearly that of political exile. This would have affected mainly the remnants of the Gaelic aristocracy in the eighteenth century. Relatively few Irish speakers travelled abroad before 1800. Second, the instances of deoraiocht after 1800 are confined to the learned register, which was far removed from the speech of the masses (Doyle, A History 141-57). If emigration was indeed viewed as a form of deoraiocht, as Miller claims, one would expect this word to occur in the folklore collected from speakers born before 1850, for example, in accounts of the Famine and its aftermath. And yet, if one reads oral material referring to emigration, one finds simply expressions like $d u l$ thar sáile 'to go overseas':

(24) a. Na prátai dubha a rinne ár gcomharsana a scaipeadh orainn, A chuir sa phoorhouse iad a's anonn thar farraige (D: 59)

'It was the black potatoes that scattered our neighbours, That sent them to the poorhouse and over the sea'

b. A's gurbh é dúchan na bprátai a chuir thar sáile muid, Ag saothrú páighe go Baltimore (D: 70)

'And it was the potato blight that sent us over the sea, To Baltimore to earn our living'

c. An chuid aca imthigh anúnn

Is chuadar 'na dtrúpaibh go Sasana As san go Meiriceá ’núnn $\quad$ (D: 61)

'Those who went across

In their droves to England

And from there over to America'

For Miller's claim to have credibility, one would need evidence of ar deoraiocht occurring in the spoken register before 1900. To my knowledge, such evidence is not forthcoming.

It may be felt that I have dwelt too long in section 2 on details of linguistic structure, with the object of picking holes in a work of otherwise highly impressive scholarship. But I have done so only because Miller devotes so much space to these details in his book. Furthermore, he uses these details to support a major claim of his work, namely, that Irish speakers experienced 
emigration more passively than English speakers, and this claim has been accepted since in most publications on Irish emigration to the United States. This in turn has led to a very false image of Irish speakers and their ability to cope with a new environment. It is important to correct this misrepresentation of linguistic practice and the culture associated with it.

The linguistic argument is not the only one put forward in support of the view that Irish speakers did not fare as well as English speakers. It is also asserted that since the former group came from the most disadvantaged areas of the west of Ireland, they were less prepared for emigration than those from the Anglophone midlands and east of the country. This argument rests on a firmer factual basis than the linguistic one-nobody would deny that in 1850 the west of Ireland was worse off than the rest of the country. The question is whether there is any hard evidence that Irish speakers from the west proved less able to make their way in the New World than English speakers? To answer this, we must first examine the sociolinguistic conditions obtaining in the Ireland they left behind.

\section{IRISH AND ENGLISH IN THE $19^{\mathrm{TH}}$ CENTURY}

By 1800 , being an Irish speaker in Ireland put one at a disadvantage. This has been well documented by many authors, e.g. Doyle (A History 107-41, "Language"). Whether it was an encounter with the landlord's agent, or a trip to the local town to sell one's cow, Irish speakers were at risk of being cheated in financial transactions. The same applied to the legal system, where they were at the mercy of interpreters. They were exposed to the ridicule of their fellowcountrymen for speaking a "backward language." Their spiritual leaders failed to provide them with much by way of support, for the most part acquiescing in the change to English which gathered momentum as the century progressed.

Whatever discrimination Irish speakers faced on arrival in North America, it can hardly have been worse than what they were accustomed to in their home country. Speakers of minority languages from an early age develop stratagems for surviving in a hostile linguistic environment. By the time the Gaelic-speaking Irish arrived in America, they would already have experienced alienation in their own country and learnt to live with it.

There is a further dimension to the linguistic identity of all Irish emigrants in the post-Famine period, one connected with the way that they spoke English. The Irish manner of speaking English has often been commented on, in 
both positive and negative terms. Until very recently, the commentary tended to be negative; at best, it was perceived as part of the overall comical character of the Irish, one which contributed to the composition of the stage Irishman. Whether the newcomers had English as their first and only language, or were bilingual in Irish and English, was irrelevant as far as the American listener was concerned: they all spoke with a brogue.

Maurice Kavanagh, an Irish speaker from Kerry who emigrated to America in 1910, described how he and other emigrants tried to adapt linguistically in the New World:

(25) Gan amhras, fé mar a dúirt an seanfhocal, nuair a raghair 'on Róimh bí id Rómhánach leo. Ach mar gheall air sin chaitheas mórán sóinseáil a dhéanamh. Béasa agus rudai mar sin, agus ansan chomh fada leis an mBéarla dhó na fats and na fys a bhi againne agus chaitheamar toning down a dhéanamh orthu san. (K: 79)

Of course, as the proverb said, when in Rome do as the Romans do. But that's why I had to make a lot of changes. My manners and suchlike, and then as regards English, we were all fats [= whats] and fys [= whys] and we had to tone those down.

What is striking is that the speaker does not mention Irish but talks instead of the features of his Irish accent that needed to be toned down. The feature he alludes to, that of substituting the sound /f/ for $/ \mathrm{w} /$, was common among English and Irish speakers alike in the west of Ireland, and hence became associated with a broad Irish accent.

In Ireland, English speakers may have felt themselves to be a cut above the Irish speakers, but in the United States, they were just part of the impoverished hordes who arrived in the 1840s:

Anglo-American Protestants did not welcome Irish Catholics, who were the first group to create social problems in American cities. The Irish lived in vermin-infested tenements, on streets that were open sewers, in slovenly neighborhoods, and manifested drunkenness, violence, family disputes and breakups, crime, disease, and mental disorders. (McCaffrey 2)

In Ireland, it was believed that a knowledge of English provided people with a distinct economic advantage. One would expect that it would have conferred the same advantage on emigrants to the United States, in comparison with their counterparts from non-English speaking countries. Nevertheless, up to the First World War few Irish managed to find non-manual employment: 
Yet only a tiny number of either Irish immigrant men or women secured jobs in the lower echelons of the white-collar hierarchy.... The advantages of a sound elementary education and fluency in English, however, were not especially helpful to peasant boys and girls unfamiliar with an urban industrial economy or even entrepreneurial ways. (Meagher 48)

Most other immigrants from Europe before 1900 were at a severe disadvantage in terms of language compared to the Irish. And yet they managed to settle and prosper, both in towns and in the countryside. In the case of the Germans, they succeeded in finding better jobs than the Irish:

Irish immigrants worked much more often in unskilled jobs and much less often in skilled and professional positions than both native-born Americans and Germans, the other principal immigrant group in the United States before the 1880s. (Kenny 149-50)

The belief in the talismanic power of language to change personality and culture has, I would contend, led us to overestimate the effect of the language change in Ireland, and subsequently, its influence on emigrants. English became the dominant language in Ireland in the nineteenth century-nobody would deny this fact. The stigma of speaking Irish was removed. But contrary to expectations, learning English did not open up new opportunities for the smallholders of western Ireland, at least not immediately. ${ }^{17}$ For most children, the only alternative to drudgery and poverty was emigration. And once they arrived in North America, they were simply Irish — nobody cared much what language they spoke back home.

\section{ACCOUNTS BY IRISH SPEAKERS OF THEIR EXPERIENCES}

Writing of the period 1870-1921, Miller points out that Irish-American society was not a homogeneous entity. One of the lines of division he mentions is language:

Catholic Irish-America itself was deeply divided in a variety of ways: for example, between Irish- and American-born generations; among different waves of emigrants, in different stages of affluence and adaptation; between the English-speaking majority and the half-million or so who still spoke Irish as their primary or only language. (Miller 494)

Once again, it is difficult to determine the basis for the linguistic division the writer postulates, apart from the obvious difference between the languages

\footnotetext{
17 Thanks to Emmet de Barra for drawing my attention to this (p.c.).
} 
themselves. Miller quotes extensively from Irish-language sources in a section devoted to alienation among immigrants (Miller 506-20), interspersing his account with remarks like the following:

However, for a large minority of post-Famine emigrants, especially for western Irishspeakers and others whose backgrounds ill fitted them for urban-industrial life, feelings of unhappy exile were so ingrained that they helped shape the emigrants' "reality" by affecting their responses to American conditions. (Miller 512)

...peasant emigrants — particularly Irish-speakers — were generally naïve and unsophisticated, most attached to kinsmen and familiar scenes, most likely to have emigrated passively rather than purposely, and least prepared by training or outlook for the "ruthless" efficiency of urban-industrial society. ${ }^{18}$ (Miller 518)

I agree that some of the few texts we have in Irish from this period stress the negative in the New World, but so do many of the English-language ones. What one needs is clear evidence that language contributed significantly to the feeling of alienation. The only reliable source for this kind of evidence are the words of Irish-speaking emigrants.

Accounts of emigration in the Irish language are scarce, mainly because the emigrants were not literate in this language. The earliest post-Famine source ${ }^{19} \mathrm{I}$ have found that mentions language is the following, ${ }^{20}$ which refers to the period c. 1900 :

(26) Creidim go raibh cineál cumhai orm fosta san áit eile, i measc daoine nach mbiodh acu ach Béarla agus teangacha coimhthiocha eile, agus ba é sin, nios mó ná an fuacht, a bhi mo thiomáint isteach go dtí na mianaigh. (RMS: 98-99)

I think that I was kind of lonely as well in the other place, among people who only spoke English and other foreign languages, and it was that, more than the cold, which was driving me in to the mines.

\footnotetext{
${ }^{18}$ Note the reappearance of the notion that Irish speakers emigrated "passively" while English speakers emigrated "purposely."

${ }^{19}$ A reviewer mentions the existence of letters from the period 1820-1850 written by Pádraig Phiarais Cundún (Ó Foghludha). I am specifically interested in the post-Famine period, and hence do not refer to these. Also, the letters make no specific mention of Irish as opposed to English. As with the evidence put forward in section 2, all we can go on are accounts from the twentieth century: we have no way of knowing for certain how an emigrant from 1850 would have felt about language.

${ }^{20}$ Interestingly, although Miller several times refers to the English translation of this work, he does not quote this passage. This is strange, as it would have strengthened his argument.
} 
In the twentieth century, an emigrant from Corca Dhuibhne (County Kerry) describes the hostility he experienced from English-speaking Irish people when he spoke Irish:

(27) Bhí beagán Eireannach ann a bhí an-mhailíseach agus an-ghránna liomsa i dtaobh ná beadh béasa agam agus Gaeilge a labhairt in áit ina mbiodh daoine ná biodh si acu. (AS: 136)

There were a few Irish people who were very malicious and nasty to me because I wouldn't be polite, seeing as I spoke Irish in situations where there were people who couldn't speak it.

The same author admits, however, that his behaviour was different from that of other Irish speakers:

(28) Bhí Éireannaigh eile ann a bhi chomh suarach agus a lig orthu ná raibh a dteanga féin acu, agus i acu chomh slachtmhar, nó b'fhéidir nios slachtmhaire, ná mar a bhí agam féin, ach fós an tsean-aicid, ceann fé agus náire go bhfaighfi amach gur ó Éirinn tú agus gan agat ach do theanga féin. (AS: 120)

There were other Irish people who were so mean-spirited that they pretended that they couldn't speak their own language, even though they could speak it as well as, or even better than me, but there you have it - the old complaint, shame and embarrassment in case somebody would discover that you were from Ireland and could only speak your own language.

It is worth noting in the above passage that "being from Ireland" was regarded as a stigma as heavy as speaking Irish. Obviously, a different language immediately marks one out as being alien, and presumably the hope was that by speaking English one would pass unnoticed in the new environment.

Ó Cinnéide's experience would certainly confirm Miller's hypothesis of their being a linguistic divide. But if most Irish speakers chose to suppress their knowledge of the language, and communicate through English, then the divide would not have manifested itself. The Irish speakers had the same names, the same religion, the same background, and in the United States at least, the same language as the English speakers. And they overwhelmingly chose to express their identity in the same way.

Numerous studies have been written about Irish American communities in the hundred years after the Famine. Two of them (Nilsen, "Thinking of Monday," "The Language") deal specifically with language; another (Moreton), contains much information about language attitudes. The community dealt with in Nilsen's articles, that of Portland, Maine, is interesting in that several 
generations of people from Irish-speaking Conamara emigrated there. As a result, a hundred years ago Irish could be heard in the streets of Portland:

Kenneth Nilsen: Did you hear any Irish when you were working?

Philip Foley: Sure. Irish was all there was.

Kenneth Nilsen: How many people do you think were here who had Irish?...

Philip Foley: There were a couple of thousand, anyway. (Nilsen, "The Language" 316)

Despite the size of the community, and the fact that they were concentrated in one city, intergenerational transmission of Irish does not seem to have taken place here: "Irish was only rarely passed on to the next generation" (Nilsen, "The Language" 327). This suggests that there was no will on the part of the speakers to maintain the language, which in turn implies that it was not an essential part of their identity.

Moreton is an account of the Blasket Islanders who lived in the Hungry Hill district of Springfield, Massachussets. ${ }^{21}$ While he is primarily interested in the Irish people he met there, and the contrast between the small island they had left and their new environment, language does come up in this interviews. One of the leading members of the community, Michael Carney, wrote about his life as an emigrant (Carney and Hayes). The Hungry Hill community also featured in a television documentary (Feiritéar). In the many statements of Irish speakers contained in these sources, I have been unable to find a single one that stresses the importance of language. Far more typical is the view expressed below. The speaker, a Blasket Islander who married an Irishspeaker from the adjoining mainland, is replying to a question about passing on Irish to their children:

Teaching them Irish would have been "terrible," she said. "If we wanted to say anything — myself and my husband — that we didn't want them to know, we'd be talking in Irish.

They had no notion to learn it, so why would we force them?" (Moreton 255)

Michael Carney's attitudes about identity and language are equally revealing. He came from the Blasket Island (in Corca Dhuibhne, County Kerry), a place which has been turned into an icon of Gaelicness in the last eighty years or so. He was of the same generation as Tomás Ó Cinnéide, the writer quoted above who complained about Irish speakers rejecting their language. Unlike Ó Cinnéide, though, Carney was pragmatic about language use:

\footnotetext{
${ }^{21}$ Another work that deals briefly with this community is Nic Craith's The Vanishing World of the Islandman.
} 
But there was no need for emigrants to speak Irish in America. Some of us would speak it just for the fun of it - just to keep the Irish alive. (Carney and Hayes 162-63)

He was proud of his Gaelic heritage, but he was far prouder of his success in the New World:

The judge gave a brief speech. He said that he wanted us to become citizens, but he wanted us to maintain our ethnic heritage. I liked that a lot. It was the same as my view on the subject. (Carney and Hayes 150)

Maintaining his ethnic heritage had its limits:

Our family name in Ireland was "Ó Cearna." When we came to America, we all dropped the "Ó" in our last name. This shortened and "Americanized" our name. It was common among Irish people. We used to say that we dropped the "Ó" in the ocean when we came over. (Carney and Hayes 145) ${ }^{22}$

This is a classic case of the immigrant who wants to fit in, to become part of the new environment. It is unlikely that Tomás Ó Cinnéide would have approved, and it reveals the kind of attitude that has received much censure from commentators in Ireland. But Michael Carney was not ashamed of this approach to life in the US. For him, this was simply what an emigrant should do on coming to the New World.

Hungry Hill in Springfield was not an Irish-speaking enclave. It was an Irish-American neighbourhood, whose inhabitants came from all over Ireland. There is no sense that speaking Irish was frowned upon by the other Irish residents: "Some people would even speak Irish outside the church on a Sunday morning after Mass" (Carney and Hayes 153). However, it was in the institutions of Irish America, such as the parish church or the John Boyle O'Reilly Club, that the Blasket Islanders found support and a sense of identity. My impression is that their Blasket Island heritage was of far more importance to those who wrote about them and interviewed them, than it was to the islanders themselves.

Summing up, there is little evidence that Irish speakers, as opposed to English speakers, felt any extra sense of alienation in America. Far from it,

\footnotetext{
${ }^{22} \mathrm{~A}$ reviewer points out that the whole question of the retention or Anglicising of names among immigrants is a complex issue. L1 Irish speakers tended to use the English forms of their names in Ireland, and were certainly familiar with them by the time they emigrated. The process of Americanisation would not have been such a radical step as for immigrants with other linguistic backgrounds.
} 
America offered opportunities of mixing with other Irish people that would not have been available to them anywhere in Ireland except Dublin. Furthermore, unlike Ireland, where Irish speakers in general and Blasket Islanders in particular were regarded as some kind of curiosity, a relic from the past, in places like Springfield they were treated on a par with other Irish Americans. Michael Carney gave his verdict on the transition to the new country in the following words: "I realize that my decision to emigrate to America was the right one for us" (Carney and Hayes 163).

\section{CONCLUSION}

This article took at its starting point the assertion of Kerby Miller that Irish speakers had a more negative experience of emigration to the US than English speakers. In sections 2 and 3, I examined two concrete pieces of language data that Miller bases this assertion upon. We saw that there was absolutely nothing in the structure or lexical semantics of Irish that substantiates his claim. I should add that this finding does not take from the overall value of Miller's work on Irish emigration to the US. However, it does mean that his statements on language need to be modified considerably.

I then turned to the sociolinguistics of Irish and English in the nineteenth century. I argued there that unlike other languages, the disadvantages of speaking Irish in the US were no greater than they were in Ireland, and that Irish speakers were used to negotiating a modus vivendi with English from an early age.

Finally, I examined the evidence provided by the words of Irish speakers concerning their experiences. Here one finds a variety of opinions, from those who felt the alienation of being in a different linguistic environment, to those who seem to have hardly noticed it. Overall, though, the impression here is that the Irish speakers felt a part of a broader Irish American community, and there is no suggestion that they formed a subgroup based on language.

America was about starting a new life. Part of that meant shedding elements of the old identity. Judging by the available evidence, most emigrants were more than happy to put the language of their youth in the background when they arrived in their new homeland. This does not have to be interpreted as outright rejection, it was simply a way of adjusting to new circumstances. 


\section{SOURCES FOR IRISH EXAMPLES}

AC Ar an gCoigrioch (Ní Dhonnchadha and Nic Eoin 2008)

AS Ar Seachrán (Tomás Ó Cinnéide)

BB Bríde Bhán (Pádraig Ua Maoileoin)

BM An Blas Muimhneach (Breandán 'ac Gearailt)

C Caiscín (Máirtín Ó Cadhain)

CC Cois na Cora (Liam Rua Mac Coitir)

CnG Corpas na Gaeilge

CR Cois na Ruachtaighe

CS Cloch Scoiltí (Diarmaid Ó Gráinne)

D An Drochshaol (Folkore)

DIL Dictionary of the Irish language, based mainly on Old and Middle Irish materials

ER The Poems of Egan O'Rahilly (Aogán Ó Rathaile)

FFE Foras Feasa ar Éirinn (Geoffrey Keating)

IA The Irish American

IG Irisleabhar na Gaedhilge

K Is Cuimhin Liom Kruger: Kruger Remembered (Tadhg Ó Dúshláine)

LSB Lámhscribhinn Staire an Bhionadaigh (Art Mac Bionaid)

MT Muinntear na Tuatha (Séamus Ó Dubhghaill)

NBMO Nuair a Bhí Mé Óg (Séamus Ó Grianna)

$\mathrm{P} \quad$ Peig (Peig Sayers)

RF Rann na Feirste (Séamus Ó Grianna)

RMS Rotha Mór an tsaoil (Micí Mac Gabhann)

SD Spotsholas na nDaoine (Muiris Bric)

SMN Seanmóiri Muighe Nuadhad (Sermons from period 1700-1850)

SPS Smaointe ar Pháis ár Slánathóra (Muiris Paor)

TBB Tri Biorgaoithe an Bháis (Geoffrey Keating)

TG Tadhg Gaedhlach (Tadhg Gaelach Ó Súilleabháin)

TNTO A Thig Ná Tit Orm (Maidhc Dainín Ó Se)

\section{WORKS CITED}

Beckett, Colm. Aodh Mac Domhnaill: dánta. An Clóchomhar, 1987.

Breatnach, R. B. Sean-Chaint na nDéise II. Dublin Institute for Advanced Studies, 1961.

Carney, Michael, and Gerald Hayes. From the Great Blasket to America: The Last Memoir of an Islander. The Collins Press, 2013.

de Bhaldraithe, Tomás. Gaeilge Chois Fhairrge: An deilbhiocht. Institiúid Ard-Léinn Bhaile Átha Cliath, 1953.

de Bhaldraithe, Tomás. English-Irish Dictionary. Oifig an tSoláthair, 1959.

Doyle, Aidan. A History of the Irish Language. Oxford UP, 2015. 
Doyle, Aidan. "Language and Literacy 1730-1880." The Cambridge History of Ireland 3, edited by James Kelly. Cambridge UP, 2018, pp. 353-379.

Doyle, Danny. Míle míle i gcéin: The Irish Language in Canada. Borealis Press, 2015.

Feiritéar, Breandán. Blasket Roots, American Dreams. RTÉ, 1997.

Kenny, Kevin. The American Irish: A History. Longman, 2000.

Lúcás, Leaslaoi. Cnuasach focal as Ros Goill. Acadamh Ríoga na hÉireann, 1986.

Mac Clúin, Seosamh. Réilthíni óir. Comhlacht Oideachais na hÉireann, 1922.

Mahon, William J. Thomas Griffin (1829-96) of Corca Dhuibhne and the Irish Community of Lawrence, Massachusetts. Department of Welsh, Aberystwyth U, 2007.

McCaffrey, Lawrence J. Textures of Irish America. Syracuse UP, 1992.

McKenna, Lambert. English-Irish Dictionary. Oifig Díolta Foillseacháin Rialtais, 1935.

McQuillan, Peter. Modality and Grammar: A History of the Irish Subjunctive. Department of Old Irish, Maynooth, 2002.

McQuillan, Peter. Native and Natural. Cork UP, 2004.

Meagher, Timothy J. Inventing Irish America: Generation, Class, and Ethnic Identity in a New England City, 1880-1928. U of Notre Dame P, 2001.

Miller, Kerby A. Emigrants and Exiles: Ireland and the Irish Exodus to North America. Oxford UP, 1985.

Moreton, Cole. Hungry for Home: Leaving the Blaskets: A Journey from the Edge of Ireland. Viking Press, 2000.

Ní Bhroiméil, Úna. Building Irish Identity in America 1870-1915: The Gaelic Revival. Four Courts Press, 2003.

Ní Dhonnchadha, Aisling, and Máirín Nic Eoin, editors. Ar an gcoigcríoch: díolaim litríochta ar scéal na himirice. Cló Iar-Chonnachta, 2008.

Nic Craith, Máiréad. The Vanishing World of the Islandman. Palgrave Macmillan, 2019.

Nic Congáil, Ríona et al., editors. Litríocht na Gaeilge ar fud an domhain. LeabhairComhar, 2015.

Nilsen, Kenneth. "Thinking of Monday: The Irish Speakers of Portland, Maine.” Éire-Ireland, vol. 25, no. 1, 1990, 6-19.

Nilsen, Kenneth “"The Language that the Strangers do not Know': The Galway Gaeltacht of Portland, Maine in the Twentieth Century." They Change their Sky: The Irish in Maine, edited by Michael C. Connolly. U of Maine P, 2004, pp. 297-339.

Nilsen, Kenneth. "An Ghaeilge in Oirthear Cheanada." Séimhfhear suairc: Aistí in ómós don Ollamh Breandán Ó Conchúir, edited by Seán Ó Coileáin et al. An Sagart, 2013, pp. 262-279.

Ó Buachalla, Breandán. Cnuasach Chléire. Institiúid Ard-Léinn Bhaile Átha Cliath, 2017.

Ó Conaire, Pádraig. Deoraidheacht. Connradh na Gaedhilge, 1910.

Ó Cuív, Brian. Cnósach focal ó Bhaile Bhúirne. Institiúid Ard-Léighinn Bhaile Átha Cliath, 1947.

Ó Curnáin, Brian. The Irish of Iorras Aithneach. Dublin Institute for Advanced Studies, 2007.

Ó Dónaill, Niall. Foclóir Gaeilge-Béarla. Oifig an tSoláthair, 1977.

Ó Foghludha, Risteárd. Pádraig Phiarais Cúndún 1777-1856. Oifig Díolta Foillseacháin Rialtais, 1932.

Ó hAnnracháin, Stiofán, editor. Go Meiriceá siar: cnuasach aistí. An Clóchomhar, 1979. 
Ó Máille, Tomás. Liosta focal as Ros Muc. Irish Academic Press, 1974.

Sumner, Natasha, and Aidan Doyle, editors. North American Gaels. McGill UP, 2020.

Ua Conmhacáin, Uáitéar. 'Caoineadh an deoraí ó Éirinn.' An Claidheamh Soluis: 533, 1899.

Wagner, Heinrich. Gaeilge Theilinn. Institiúid Ard-Léinn Bhaile Átha Cliath, 1959.

\section{DOŚWIADCZENIE EMIGRACJI DO AMERYKI PÓŁNOCNEJ PRZEZ UŻYTKOWNIKÓW JĘZYKA IRLANDZKIEGO}

\section{Streszczenie}

Artykuł kwestionuje pogląd powszechny w historycznych opracowaniach emigracji z Irlandii do Nowego Świata jakoby osoby posługujące się językiem irlandzkim przyjmowały postawę bardziej bierną i fatalistyczną w porównaniu do osób anglojęzycznych oraz postrzegały emigrację jako formę wygnania. W części pierwszej, wykazano brak podstaw empirycznych i teoretycznych dla tego poglądu w oparciu o argumentację językową. Nie ma nic w języku irlandzkim co wskazywałoby na pasywność jego użytkowników. W drugiej części artykułu wskazano na opisy życia w Ameryce, z których wynika, że zarówno osoby mówiące w języku irlandzkim jak i angielskim miały szereg różnych doświadczeń w nowym środowisku. Nie dostarczają one żadnych dowodów na istotny wpływ języka na zwiększenie poczucia alienacji wśród emigrantów.

\section{Przekład angielskiego abstraktu} Maria Bloch-Trojnar

Słowa kluczowe: emigracja; Whorf; Miller; modalność; wygnanie. 